\title{
Large intramedullary bronchogenic cyst of the cervical spine: illustrative case
}

\author{
Adela Wu, MD, ${ }^{1}$ Mahesh Patel, MD, ${ }^{2}$ Dawn Darbonne, MD, ${ }^{3}$ and Harminder Singh, MD ${ }^{1,4}$ \\ ${ }^{1}$ Department of Neurosurgery, Stanford University Medical Center, Stanford, California; and Departments of ${ }^{2}$ Radiology and ${ }^{3}$ Pathology, and ${ }^{4}$ Division of Neurosurgery, \\ Santa Clara Valley Medical Center, San Jose, California
}

BACKGROUND Spinal bronchogenic cysts are rare entities arising from errors in embryogenesis and consisting of respiratory epithelial cells. To date, there are three other published accounts of intramedullary cysts, which were partially resected and thereby warrant close follow-up and monitoring. The authors present an illustrative case of a patient presenting with Klippel-Feil anomaly and a large intramedullary bronchogenic cyst in the upper cervical spine.

OBSERVATIONS The authors noted fusion of the C5-6 laminae as they performed the C2-6 laminectomy. After dural opening, an intramedullary lesion with a smooth, fibrous component emerging from the dorsal spinal cord was immediately observed. The dorsal spinal columns were not involved with this cyst wall or the other smaller cysts, which all contained gray fluid. The cyst walls were partially resected and sent for pathological examination.

LESSONS Spinal developmental cysts are associated with other anatomical anomalies, such as Klippel-Feil anomaly, arising from errors in embryogenesis. For intramedullary lesions such as this patient's bronchogenic cyst, partial resection and decompression are the goals of surgery because aggressive debulking may lead to neurological compromise. Close imaging follow-up is warranted.

https://thejns.org/doi/abs/10.3171/CASE2115

KEYWORDS developmental cyst; bronchogenic cyst; intramedullary; cervical spine; cystic

Bronchogenic cysts are formed as a result of abnormal budding of the bronchial tree and characterized by ciliated, pseudostratified columnar epithelial lining of the cyst walls., ${ }^{1,2}$ These developmental cysts are typically located in the lung or mediastinum. Spinal bronchogenic cysts are rare, with fewer than 30 cases published and the vast majority being extramedullary lesions (Table 1). ${ }^{2-16}$ Three prior accounts described intramedullary bronchogenic cysts (Table 1). ${ }^{1,17,18}$ We present our experience with a large intramedullary bronchogenic cyst located in the cervical spine.

\section{Illustrative Case}

\section{History and Physical Examination}

A 48-year-old male with a past medical history of hypertension initially presented with at least 1 year of neck pain and intermittent right arm numbness. By the time he was evaluated by a neurosurgeon, the patient had experienced 6 months of right arm numbness and weakness, including difficulty holding objects, in addition to his neck pain. The patient had no symptoms involving his left arm, lower extremities, or bowel and bladder dysfunction.
The patient's physical examination was notable for $4 / 5$ motor strength in all muscle groups of the right arm as well as numbness over the medial aspect of the right midforearm. The patient was neurologically intact otherwise.

Contrast-enhanced magnetic resonance imaging (MRI) of the patient's cervical spine demonstrated a markedly expansile $7 \times 1.3 \times$ 2.0-cm multiseptated cystic intramedullary spinal cord lesion located at C2-6 with central heterogeneous and nodular enhancing components (Fig. 1). Enhancement of a septation within the midaspect of the lesion was seen, revealing marked effacement of the surrounding cerebrospinal fluid (CSF) and indolent expansion of the spinal canal. Based on the MRI findings, a differential diagnosis favoring an intramedullary neoplasm of astrocytoma or ependymoma was deemed most likely.

Of note, prior radiographs (XRs) and computed tomography (CT) imaging of the patient's cervical spine indicated a rudimentary disc space at C5-6 with partial fusion of the facets and posterior elements as well as an overall decreased size of the C5-6 vertebral bodies, suggesting a congenital Klippel-Feil spectrum abnormality. However, the patient did not exhibit classic external characteristics of Klippel-Feil syndrome, such as short neck or low hairline, on physical examination.

ABBREVIATIONS CSF = cerebrospinal fluid; $\mathrm{CT}=$ computed tomography; $\mathrm{MRI}=$ magnetic resonance imaging; $\mathrm{XR}=$ radiograph . INCLUDE WHEN CITING Published March 29, 2021; DOI: 10.3171/CASE2115.

SUBMITTED January 7, 2021. ACCEPTED January 14, 2021.

(c) 2021 The authors, CC BY-NC-ND 4.0 (http://creativecommons.org/licenses/by-nc-nd/4.0/) 
TABLE 1. Extramedullary and intramedullary spinal bronchogenic cysts in previously published case reports and series

\begin{tabular}{|c|c|c|c|c|c|c|c|}
\hline Authors \& Yrs & $\begin{array}{l}\text { Age } \\
\text { (yrs) }\end{array}$ & Sex & Presentation & Location & $\begin{array}{l}\text { Size } \\
(\mathrm{cm})\end{array}$ & Resection & Follow-Up \\
\hline \multicolumn{8}{|c|}{ Extramedullary bronchogenic cysts } \\
\hline $\begin{array}{l}\text { Wilkinson et al., } \\
1992^{4}\end{array}$ & 55 & $\mathrm{~F}$ & $\begin{array}{l}\text { Rt arm pain \& paresthesia, } \\
2 \text { wks }\end{array}$ & C3-4 & $\begin{array}{l}1 \times 0.8 \\
\times 0.4\end{array}$ & Partial & Resolution of symptoms at $1 \mathrm{yr}$ \\
\hline Baba et al., $1995^{5}$ & 16 & M & Suboccipital pain & $\mathrm{C} 1$ & & Complete & $\begin{array}{l}\text { Resolution of symptoms \& no } \\
\text { recurrence at } 1 \mathrm{yr}\end{array}$ \\
\hline Rao et al., $1999^{6}$ & 18 & M & Rt arm pain \& weakness, 6 wks & $\mathrm{C} 2-3$ & & Complete & Resolution of symptoms at 3 mos \\
\hline $\begin{array}{l}\text { Baumann et al., } \\
2005^{7}\end{array}$ & 41 & $M$ & $\begin{array}{l}\text { Chronic back pain, acute It leg } \\
\text { pain }\end{array}$ & $\mathrm{T} 12-\mathrm{L} 1$ & 5 & Partial & $\begin{array}{l}\text { Resolution of paresthesias but } \\
\text { recurrence of pain at } 3 \text { mos w/o disease } \\
\text { recurrence }\end{array}$ \\
\hline $\begin{array}{l}\text { Chongyi et al., } \\
2008^{8}\end{array}$ & 28 & M & $\begin{array}{l}\text { Back pain, } 1 \mathrm{yr} \text {; leg weakness } \\
\text { \& numbness, } 2 \text { wks }\end{array}$ & L1 & $\begin{array}{l}2 \times 1.7 \\
\times 1.5\end{array}$ & Partial & Immediate resolution of symptoms \\
\hline Liu et al., $2015^{11}$ & 55 & M & Paraplegia, 5 days & T5-6 & $\begin{array}{c}2 \times 2 \times \\
3\end{array}$ & Partial & Resolution of symptoms at $1 \mathrm{yr}$ \\
\hline Zou et al., $2015^{12}$ & 44 & $\mathrm{~F}$ & $\begin{array}{l}\text { Back pain, } 9 \text { yrs; leg } \\
\text { weakness, } 2 \text { yrs }\end{array}$ & Conus, L3-4 & $\begin{aligned} 2 & \times 1.5 \\
& \times 1\end{aligned}$ & Complete & $\begin{array}{l}\text { No recurrence \& resolution of } \\
\text { symptoms at } 6 \text { mos }\end{array}$ \\
\hline \multirow[t]{3}{*}{ Chen et al., $2015^{13}$} & 24 & M & Back pain, 1 mo & L4-5, conus & & Partial & Immediate resolution of symptoms \\
\hline & 29 & M & $\begin{array}{l}\text { Back pain, } 1 \text { mo; leg } \\
\text { numbness, } 1 \text { wk }\end{array}$ & T9-10 & & Partial & Immediate resolution of symptoms \\
\hline & 34 & M & $\begin{array}{l}\text { Neck pain \& It leg numbness, } \\
4 \text { mos }\end{array}$ & $\begin{array}{l}\text { Craniocervical } \\
\text { junction }\end{array}$ & $\begin{array}{c}0.9 \times \\
1.8 \times \\
1.6\end{array}$ & Complete & Immediate resolution of symptoms \\
\hline Jha et al., $2018^{16}$ & 43 & M & Neck pain, 4 mos & $\mathrm{C} 2-4$ & $2 \times 2$ & Complete & $\begin{array}{l}\text { Resolution of symptoms \& no } \\
\text { recurrence at } 1 \mathrm{yr}\end{array}$ \\
\hline \multirow[t]{6}{*}{ Weng et al., $2018^{2}$} & 23 & M & Neck pain, 4 mos & C3-4 & 2 & Partial & No recurrence at 54 mos \\
\hline & 15 & M & Low back pain, 10 mos & L1-2 & 4 & Partial & Recurrence at 60 mos \\
\hline & 25 & $\mathrm{~F}$ & $\begin{array}{l}\text { Neck pain \& bilat arm } \\
\text { numbness, } 2 \text { mos }\end{array}$ & C2-4 & 3 & Complete & $\begin{array}{l}\text { Resolution of symptoms at } 19 \text { days; } \\
\text { no recurrence at } 42 \text { mos }\end{array}$ \\
\hline & 41 & $\mathrm{~F}$ & $\begin{array}{l}\text { Neck \& shoulder numbness, } \\
2 \text { mos }\end{array}$ & $\mathrm{C} 4$ & 2.5 & Partial & No recurrence at 81 mos \\
\hline & 6 & M & Bilat arm tremor, $1 \mathrm{yr}$ & C2-5 & 2 & Partial & Recurrence at 46 mos \\
\hline & 36 & $\mathrm{~F}$ & Occipitocervical pain, $1 \mathrm{mo}$ & $\begin{array}{l}\text { Craniocervical } \\
\text { junction }\end{array}$ & 3 & Complete & No recurrence at 12 mos \\
\hline \multicolumn{8}{|c|}{ Intramedullary bronchogenic cysts } \\
\hline Yilmaz et al., $2009^{17}$ & 17 & M & $\begin{array}{l}\text { Back pain, } 2 \text { mos; } \\
\text { leg paresthesias }\end{array}$ & Conus, T12-L1 & 1.5 & Partial & $\begin{array}{l}\text { Resolution of symptoms \& no } \\
\text { recurrence at } 1 \mathrm{mo}\end{array}$ \\
\hline
\end{tabular}


» CONTINUED FROM PAGE 2

TABLE 1. Extramedullary and intramedullary spinal bronchogenic cysts in previously published case reports and series

\begin{tabular}{cccccccc}
\hline Authors \& Yrs & $\begin{array}{c}\text { Age } \\
\text { (yrs) }\end{array}$ & Sex & Presentation & Location & $\begin{array}{c}\text { Size } \\
(\mathrm{cm})\end{array}$ & Resection & Follow-Up \\
\hline Dusad et al., 20171 & 18 & $\mathrm{M}$ & $\begin{array}{c}\text { Upper back pain, leg } \\
\text { weakness, urinary retention, } \\
\text { 3 yrs }\end{array}$ & T2-3 & $2 \times 1.6$ & Partial & Improvement at 1-mo follow-up \\
\hline Chen et al., 201918 & 46 & F & $\begin{array}{c}\text { Neck pain, } 6 \text { mos; bilat arm } \\
\text { numbness, 1 mo }\end{array}$ & $\begin{array}{c}\text { Foramen } \\
\text { magnum }\end{array}$ & Partial & Resolution of symptoms at 1 mo \\
\hline
\end{tabular}

Furthermore, lateral XRs showed attenuation of C3-4 laminae with increased lucency compared with surrounding vertebrae, suggesting indolent erosion due to a long-standing disease process.

\section{Operation}

The patient underwent a C2-6 laminectomy for intramedullary tumor resection. We opted for laminectomy over laminoplasty to allow more room for the spinal cord to expand if the lesion's associated cyst were to reaccumulate. Because the patient had good cervical lordosis, we decided to proceed with laminectomy without instrumented fusion.

A midline dural incision was made with the edges elevated. The spinal cord involving a smooth, fibrous cyst wall component was visualized emerging from the posterior spinal cord (Fig. 2A). The dorsal spinal columns were not involved with this cyst wall or the other smaller cysts, which all contained milky gray fluid. A small amount of fibrous material was removed for sampling as well as to open and drain a cyst
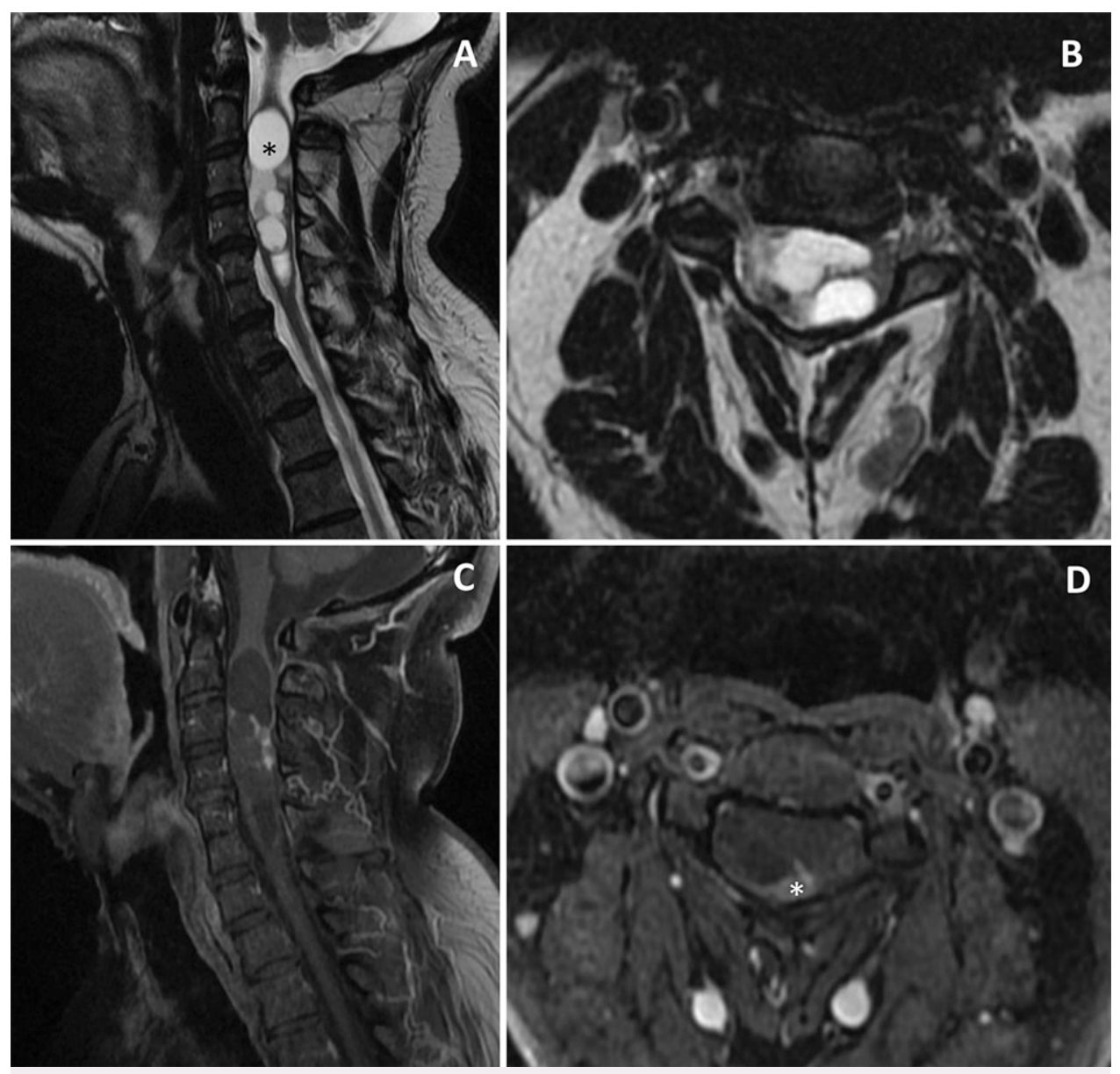

FIG. 1. Preoperative MRI with and without contrast enhancement of the cervical spine. A: Sagittal T2weighted precontrast image of the cervical spine showing a multinodular lesion and syrinx (asterisk). B: Axial T2weighted precontrast cross-sectional image of the cervical spine. C: Sagittal T1-weighted postcontrast image of the cervical spine showing a heterogeneously enhancing nodular and cystic lesion. D: Axial T1-weighted postcontrast cross-sectional image of the cervical spine showing an enhancing nodular component (asterisk). 

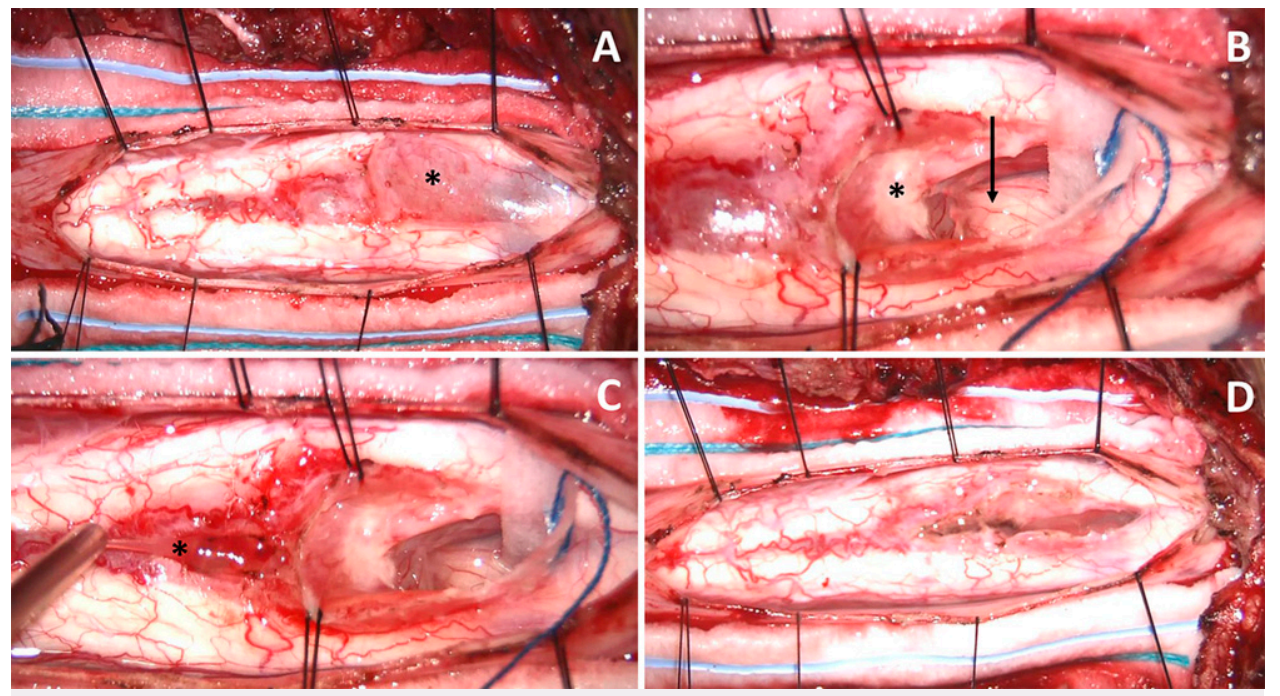

FIG. 2. Intraoperative photos of cystic intramedullary spinal bronchogenic cyst. A: Visualization of the intramedullary lesion with fibrous cyst wall after dura opening (asterisk). B: Ventral spinal cord (arrow) and cyst components (asterisk) after excision of smooth muscle fibers. C: Gray, gelatinous cyst contents (asterisk). D: Partial resection of intramedullary lesion.

containing gelatinous gray fluid, which was also sent for histopathological examination (Fig. 2B and C). Cytology for the fluid came back as amorphous globular material with rare macrophages and rare bland ciliated epithelial cells consistent with choroid plexus cells. There were a few small clumps of yellow crystalline material evacuated from within one cyst, suspicious for a scolex. Pathology for this, however, came back as scant acellular proteinaceous material. There were multiple additional cysts identified and drained. Frozen sections of the cyst wall
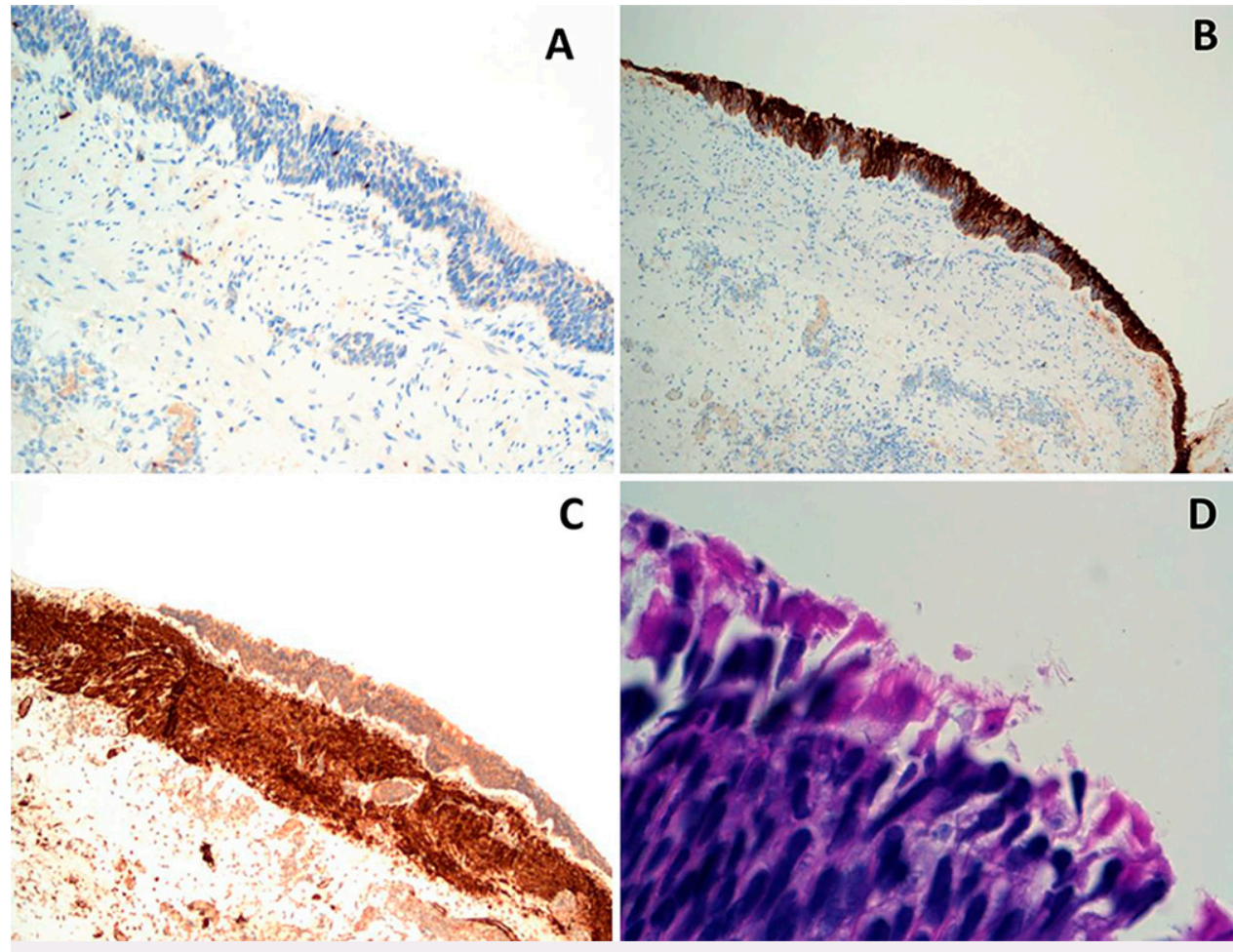

FIG. 3. Photomicrographs of biopsied cyst wall. A: Image at magnification $\times 10$ showing cyst wall section stained for cytokeratin 20 (CK20). This section is negative for CK20. B: Image at magnification $\times 10$ showing cyst wall section positively staining for CK7. C: Image at magnification $\times 10$ showing cyst wall section positively staining for and highlighting smooth muscle myosin layer beneath epithelium. D: Image at magnification $\times 40$ showing stratified columnar ciliated epithelium. 
were notable for smooth muscle without involving neural tissue or clear indication of malignancy. Given these pathological findings and the intramedullary nature of this spinal lesion, the decision for partial resection was made. Neuromonitoring was also used to guide the extent of resection. Signals (motor evoked potentials and somatosensory evoked potentials) remained stable during the case.

Histopathological findings were notable for glandular and smooth muscle tissue from the cyst wall biopsy samples as well as cilia lining the pseudostratified epithelium with an underlying layer of smooth muscle, characterizing a developmental bronchogenic cyst (Fig. 3). In addition, the results of immunohistochemical stains were positive for cytokeratin 7 and negative for cytokeratin 20 in the epithelial cells.

\section{Postoperative Course}

The patient was at his neurological baseline after the procedure. Postoperative MRI of the cervical spine at 6 weeks showed subtotal resection of the intramedullary lesion with interval decrease in the spinal cord syrinx (Fig. 4). MRI of the brain and the thoracic and lumbar spine did not reveal any other abnormalities other than a small incidental meningioma located at the T6 level. The patient's neck pain had greatly diminished by the 6-week follow-up, and his arm paresthesias were improving as well.

\section{Discussion}

\section{Observations}

After exposing the posterior elements of the cervical spine, we noted that the laminae of C5 and C6 were fused, in line with the patient's
Klippel-Feil anomaly. In addition, the laminae of C3 and C4 were thinned by the long-standing presence of the intramedullary lesion. The spinal cord involving a smooth, fibrous cyst wall component was visualized emerging from the posterior spinal cord after dural opening. Several cysts containing gray material were opened and sent for pathological specimens. Intraoperative samples of cyst walls were notable for smooth muscle without evidence of malignant features, guiding our decision for partial resection.

\section{Review}

A subset of enterogenous cysts, bronchogenic cysts are uncommon congenital lesions and developmentally derived from respiratory epithelial precursors after errors in embryogenesis at the 5th or 6th week of life. They contain various cell types, including goblet cells and ciliated, pseudostratified epithelial cells, which differentiate bronchogenic from other neurenteric cysts that consist of foregut-type cells. ${ }^{2,19}$ Bronchogenic cysts can also be differentiated from other cyst types, such as ependymal cysts that may contain ciliated cells but no smooth muscle component. Diagnosed primarily in adults, bronchogenic cysts are often located in lung parenchyma or the mediastinum, although they can be found in the neck, diaphragm, and abdomen. ${ }^{20-22}$

Spinal bronchogenic cysts are rare entities, with the vast majority presenting as extramedullary cysts that compress the cord. Of the 27 published cases of primary spinal bronchogenic cysts, only 3 were intramedullary lesions (Table 1).,17,18 We present our case of a large intradural intramedullary spinal bronchogenic cyst causing syrinx formation as well as cord compression.
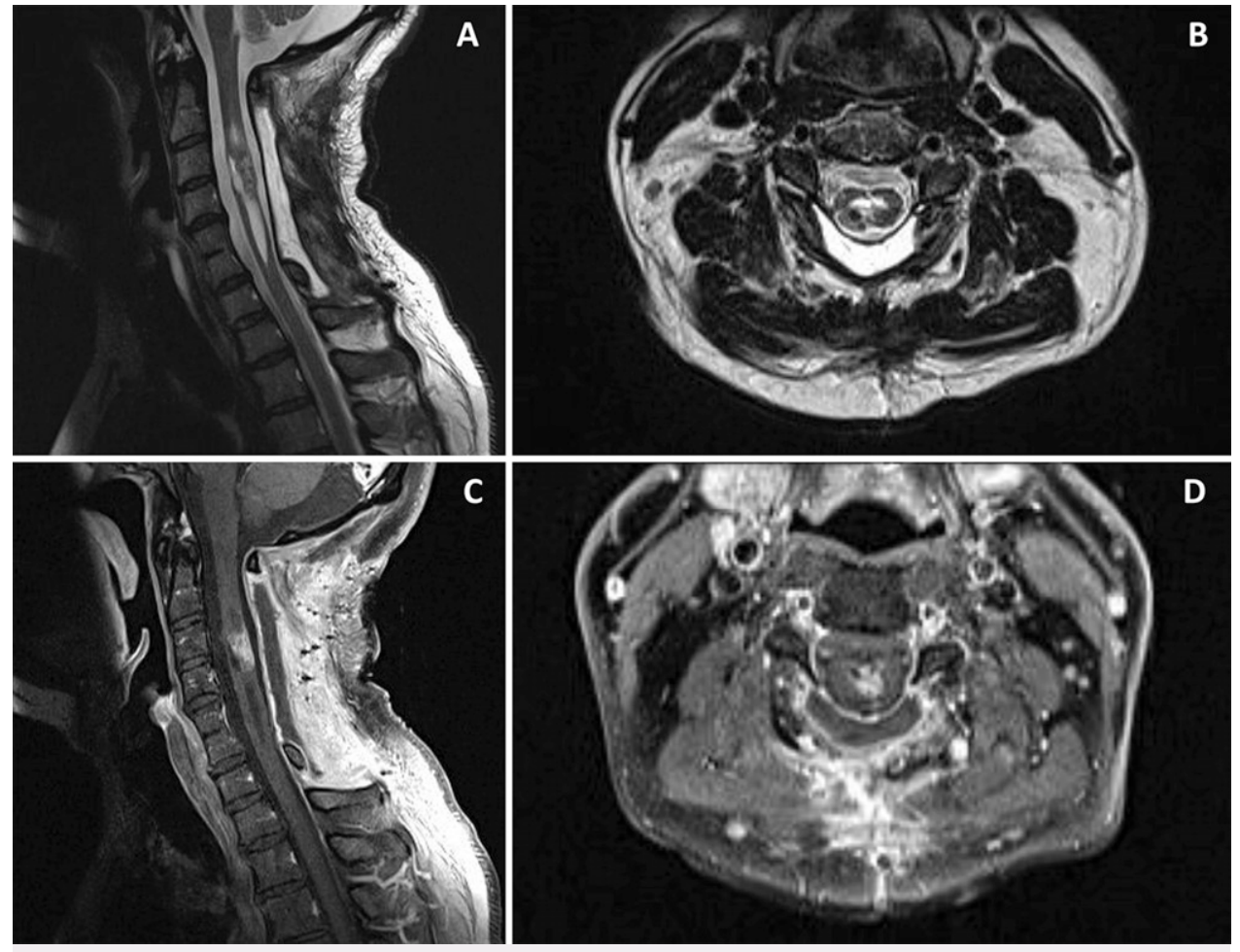

FIG. 4. Six-week postoperative MRI with and without contrast enhancement of the cervical spine. A: Sagittal T2-weighted precontrast postoperative image showing decrease in syrinx size. B: Axial T2-weighted precontrast cervical spine cross-section. C: Sagittal T1-weighted postcontrast image showing residual nodular lesion. D: Axial T1-weighted postcontrast image showing cervical spine cross-section of the enhancing lesion. 
Ranging in age from 5 months to 66 years, these patients have variable presentations, ranging from neck or extremity pain to paraplegia and debilitating bowel or bladder dysfunction. Most lesions are diagnosed at a relatively small size $(<3 \mathrm{~cm})$, whereas our patient's lesion was $7 \mathrm{~cm}$ at its greatest dimension and severely obliterated the CSF space, creating a large syrinx in the cervical spine.

Definitive diagnostic imaging involves MRI, although initial differential diagnoses may deviate from the confirmed bronchogenic cyst histopathology. According to a case series of 6 patients with extramedullary spinal bronchogenic cysts, $84.2 \%$ of the cysts were homogeneous and only $14.3 \%$ were contrast enhancing on MRI. ${ }^{2}$ Solely on the basis of imaging findings, the 6 cases were presumed to be either dermoid or neurenteric cysts before histopathological confirmation. ${ }^{2}$ In addition to MRI, CT and XR studies are helpful in contributing to the diagnosis. Often, enterogenous cysts, including bronchogenic cysts, are associated with congenital spinal abnormalities, such as anterior spina bifida, diastematomyelia, and segmentation fusion deformities, such as Klippel-Feil anomaly in our patient. ${ }^{19}$

When possible, the goal of surgical management for spinal enterogenous cysts would be gross-total resection because of their predilection for recurrence. In a cohort of patients with neurenteric cysts, the rate of recurrence was $63 \%$ among those with residual disease. ${ }^{23}$ However, complete resection is not safe for intramedullary cysts given neuronal involvement, and continued follow-up and serial imaging are critical for this patient population.

\section{Lessons}

After the muscle and fascial exposure, it is necessary to be mindful of altered anatomy, which included both eroded and fused laminae in our patient. Therefore, careful use of the drill is warranted during the laminectomy, particularly if performed en bloc.

Lessons from this case include expanding preoperative differential diagnoses to include even rare developmental entities, such as bronchogenic cysts, and using intraoperative pathology to guide resection. Because multiple frozen sections sent intraoperatively did not reveal any malignancy, the goal of the procedure was to debulk and decompress the cervical spinal cord and syrinx and safely resect as much of the cyst wall as possible without causing neurological compromise. Given the benign appearance of the spinal lesion, a less aggressive approach was warranted in order to preserve neurological function in a relatively young patient.

Intramedullary spinal bronchogenic cysts are extremely rare congenital lesions, and we add to the existing cohort of 3 published cases with our presentation of a male patient with Klippel-Feil anomaly and a large cyst distorting the cord and CSF space in the cervical spine. Although MRI is the best diagnostic imaging modality available, histopathological confirmation is crucial for identification of these neoplasms. Ideally, bronchogenic cysts would undergo gross-total resection, although partial resection and close monitoring are preferable for intramedullary lesions.

\section{References}

1. Dusad T, Kundnani V, Dutta S, et al. An unusual case of intradural intramedullary dorsal bronchogenic cyst in spine. J Spine Surg. 2017;3(3):514-518.

2. Weng JC, Ma JP, Hao SY, et al. Intradural extramedullary bronchogenic cyst: clinical and radiologic characteristics, surgical outcomes, and literature review. World Neurosurg. 2018;109:e571-e580.

3. Ho KL, Tiel R. Intraspinal bronchogenic cyst: ultrastructural study of the lining epithelium. Acta Neuropathol. 1989;78(5):513-520.

4. Wilkinson $\mathrm{N}$, Reid $\mathrm{H}$, Hughes D. Intradural bronchogenic cysts. J Clin Pathol. 1992;45(11):1032-1033.
5. Baba H, Okumura $Y$, Ando M, et al. A high cervical intradural extramedullary bronchogenic cyst. Case report. Paraplegia. 1995;33(4): 228-232.

6. Rao GP, Bhaskar G, Reddy PK. Cervical intradural extramedullary bronchiogenic cyst. Neurol India. 1999;47(1):79-81.

7. Baumann $C R$, Könü D, Glatzel M, Siegel AM. Thoracolumbar intradural extramedullary bronchiogenic cyst. Acta Neurochir (Wien). 2005;147(3):317-319.

8. Chongyi S, Meng Y, Dejun Y, et al. Lumbar intradural extramedullary bronchiogenic cyst. Eur Surg Res. 2008;40(1):26-28.

9. Ko KS, Jeun SS, Lee YS, Park CK. Sacral intraspinal bronchogenic cyst: a case report. J Korean Med Sci. 2008;23(5):895-897.

10. Arnold PM, Neff LL, Anderson KK, et al. Thoracic myelopathy secondary to intradural extramedullary bronchogenic cyst. J Spinal Cord Med. 2009;32(5):595-597.

11. Liu QP, Zhang JN, Zhang L, et al. An acute case of paraplegia and spinal bronchogenic cyst. J Orthop Sci. 2015;20(5):923-926.

12. Zou MX, Hu JR, Kang YJ, et al. Bronchogenic cyst of the conus medullaris with spinal cord tethering: a case report and review of the literature. Int J Clin Exp Pathol. 2015;8(4):3937-3942.

13. Chen J, Lai R, Li Z, et al. Case report series and review of rare intradural extramedullary neoplasms-bronchiogenic cysts. Medicine (Baltimore). 2015;94(49):e2039.

14. Ma X, Li W, Niu C, et al. Intraspinal bronchogenic cyst: series of case reports and literature review. J Spinal Cord Med. 2017;40(2):141-146.

15. Lee HD, Han SH, Park SB, et al. An intradural extramedullary bronchogenic cyst in the thoracolumbar spine: a case report. Medicine (Baltimore). 2017;96(50):e9263.

16. Jha RK, Mohanty CB, Deopujari CE, Shaikh ST. Upper cervical bronchogenic cyst: a rare condition at a rare location. J Neurosci Rural Pract. 2018;9(1):149-151.

17. Yilmaz $C$, Gulsen $S$, Sonmez E, et al. Intramedullary bronchogenic cyst of the conus medullaris. J Neurosurg Spine. 2009;11(4):477-479.

18. Chen F, Marx S, Zhang C, et al. Intramedullary bronchogenic cyst in the foramen magnum region accompanied with syringomyelia: a case report and literature review. Medicine (Baltimore). 2019;98(5):e14353.

19. McNutt SE, Mrowczynski OD, Lane J, et al. Congenital spinal cysts: an update and review of the literature. World Neurosurg. 2021;145:480-491.e9.

20. Cuypers P, De Leyn P, Cappelle L, et al. Bronchogenic cysts: a review of 20 cases. Eur J Cardiothorac Surg. 1996;10(6):393-396.

21. Jiang JH, Yen SL, Lee SY, Chuang JH. Differences in the distribution and presentation of bronchogenic cysts between adults and children. J Pediatr Surg. 2015;50(3):399-401.

22. Stewart BD, VandenBussche CJ, Leon ME. Benign lesions of the mediastinum: a review with emphasis on cytology and small biopsy specimens. Semin Diagn Pathol. 2020;37(4):199-210.

23. Garg N, Sampath S, Yasha TC, et al. Is total excision of spinal neurenteric cysts possible? Br J Neurosurg. 2008;22(2):241-251.

\section{Disclosures}

The authors report no conflict of interest concerning the materials or methods used in this study or the findings specified in this paper.

\section{Author Contributions}

Conception and design: Singh, Wu, Patel. Acquisition of data: Singh, Wu, Patel. Analysis and interpretation of data: Singh, Wu. Drafting the article: Singh, Wu. Critically revising the article: Singh, Wu. Reviewed submitted version of manuscript: Singh, Wu, Darbonne. Approved the final version of the manuscript on behalf of all authors: Singh. Study supervision: Singh.

\section{Correspondence}

Harminder Singh: Stanford University Medical Center, Stanford, CA. harman@stanford.edu. 